\section{The White House \\ Conference: The academic library agenda}

\author{
By James G. Neal \\ Dean of University Libraries \\ Indiana University
}

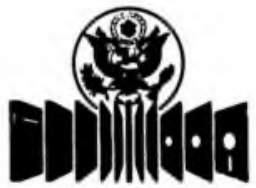
The WhIte House Conference ON LIBRARY AND INFORMATION SERVICES 1991

Solutions...that is what needs to flow from the collective deliberations and resolutions of the White House Conference on library and Information Services. The conference delegates wrestled through a cumbersome process, a rich diversity of interests, significant but largely symbolic political attention, and surprising media inattention to develop a plan that links the future health of the country to the vitality of the information and library infrastructure. Solutions can and will be forged at the national level, but the true value of the conference will be played out at the state and local levels. The resolutions must serve as catalysts for an action agenda in each state and for raising civic dialogue on the future of libraries. The ability of library professionals and citizen advocates to network effectively with the business, political, research, information, and education communities will dictate the difference between a schizophrenic week in the nation's capital and a revolution in our national thinking about and support for library and information services.

The interests of academic and research libraries were well represented at the conference and received significant attention in the resolutions. Delegates voted and accepted 95 recommendations and petitions which are being organized in the WHCLIS final report into ten subject areas: availability and access to information, structure and governance, marketing to communities, networks through technology, national information policy, preservation of information, services for diverse needs, information technology, training to reach end users, and personnel and staff development. The resolutions in each category offer outstanding opportunities for "a continued and indeed strengthened investment in academic libraries" as outlined in ACRL's pre-conference statement on the federal role in supporting the information needs of students and researchers.
The ACRL Tack Force on WHCLIS recommended six priority actions, and all are reflected in the final package of resolutions approved by the delegates:

1. Reauthorization and expansion of the Higher Education Act.

2. Reauthorization of the Library Services and Construction Act to support interlibrary cooperation and resource sharing.

3. Preservation of and access to records of our national culture

4. Expansion of support for federal programs such as the Library of Congress, National Library of Medicine, National Agriculture Library, National Archives, federal depository and Government Printing Office, subsidized postal rates and discount rates from common carriers of electronic data, and open access to information through the Freedom of Information Act.

5. Creation and funding of the National Research and Education Network.

6. Development of regulations that foster information sharing and intemational data flow.

In addition to endorsement of this federal mandate, many issues of prime concern to academic libraries are covered in the final WHCLIS report. Particularly noteworthy and demanding of coordinated follow-up are the following:

- library and information science programs in support of multicultural and multilingual populations;

- library and information service programs in support of persons with disabilities;

- a national institute for library and information services;

- networking policies and programs that ensure system compatibility;

- copyright legislation to accommodate the impact of new and emerging technologies; 
- a national research and development agenda for library and information technologies;

- library leadership role in lifelong learning programs;

- training of students in the use of libraries and information services;

- alternative delivery systems for graduate programs in library and information science;

- continuing education, staff development, and training programs;

- and a national program to strengthen library collection capabilities.

ACRL and the academic library community must continue to pursue a legislative agenda and planing process that will enable successful refinement, elaboration, and implementation of these resolutions. On the national, state, and local levels, academic librar- ians must achieve positions of leadership as conference follow-up strategies are outlined. The central issues must be taken to the faculty, the administration, state higher education officials, legislators, and citizens. State and regional conferences from which the mass of ideas streamed into WHCLIS should be reconvened to forge local action plans. ACRL chapters must play a key educational role. Libraries are part of the solution to the challenges of democracy, productivity, and literacy. The blueprint now being presented to us by WHCLIS must be translated into a new vision of our information future and provoke us to adopt innovative and bold approaches to information services

$E d$. note: James G. Neal was head of the Indiana delegation to WHCLIS and was an elected member of the Conference Resolutions Committee.

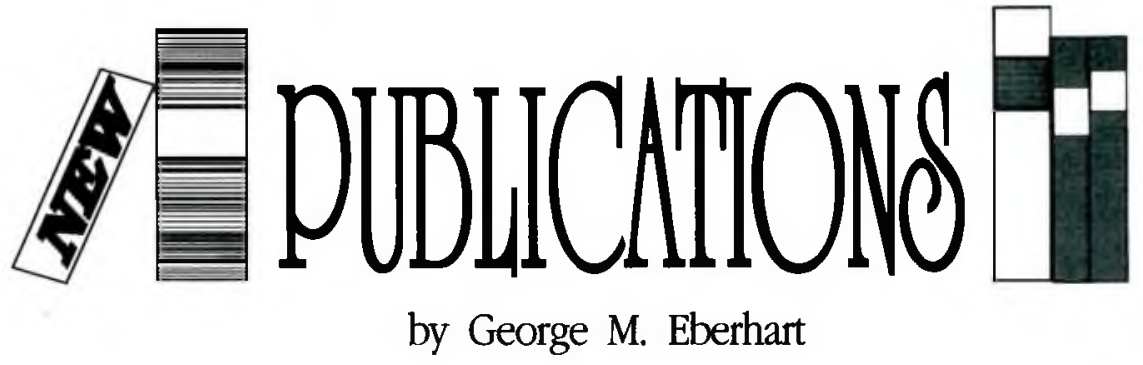

- The Academic Library in the American University, by Stephen E. Atkins (226 pages, July 1991), provides a critical analysis of the role of the academic library and how it may meet the expectations of the faculty and administration. The first chapter reviews the changes in higher education from 1638 to the present, while later chapters take up the major change that has influenced the role of the academic library in the past 20 years - the information revolution. Atkins examines how the availability of information via electronic media and the necessity for complete information access conflicts with the library's declining share of the allocation dollar. The direct result of a paper that Atkins presented at the 1986 ACRL National Conference in Baltimore, this book provides more than 30 figures and tables to illustrate his analysis. Copies are available for $\$ 35.00$ (ALA members, $\$ 31.50$ ) from the AI.A Order Department, $50 \mathrm{E}$. Huron St., Chicago, IL 60611-2795. ISBN 0-8389-0567-6.

- ALA Survey of Librarian Salaries 1991, by Mary Jo Lynch, Margaret Myers, and Jeniece Guy (57 pages, June 1991), is the seventh report prepared by ALA's Office for Library Personnel Resources showing salaries paid to incumbents in seven positions commonly found in U.S. academic and public libraries. For the first time, in this edition only salaries for full-time staff with master's degrees from an ALA-accredited graduate library are reported. A copy may be ordered for $\$ 40.00$ from the AI A Order Department, $50 \mathrm{E}$. Huron St., Chicago, IL 60611-2795. ISBN 0-8389-3401-3.

- Automating the Library with askSam: $\mathbf{A}$ Practical Handbook, by Marcia D. Talley and Virginia A. McNitt (184 pages, August 1991), provides specific instructions for using the popular askSam software for common library operations: serials check-in, acquisitions, cataloging, ILL, office management, and even hypertext. Instructions are clearly explained with many examples. A copy may be ordered for $\$ 39.50$ from the Meckler Corp., 11 Ferry Lane West, Westport, CT 06880. ISBN 088736-801-8.

- Bibliography of the Holocaust Memorial Resource and Education Center of Central Florida (399 pages, Summer 1990) is an annotated listing of the books, audiotapes, films, and videotapes in the collections at the Center, which range from anti-Semitism to war criminals. This volume is useful as a guide to the literature of the Holocaust, 